$\square$ 증 례 $\square$

$$
\begin{gathered}
\text { 양측성 폐종괴 양상을 보인 알레르기성 기관지 폐 } \\
\text { 아스폐르길루스증 } 1 \text { 예 }
\end{gathered}
$$

연세대학교 의과대학 내과학교실, 진단방사선과학교실*, 병리학교실**

고원기, 최승원, 박재민, 안강현, 김세규, 장 준, 김성규, 이원영, 최규옥*, 신동환**

$=$ Abstract $=$

\title{
A Case of Allergic Bronchopulmonary Aspergillosis Shown as Bilateral Pulmonary Masses
}

\author{
Won Ki Ko, M.D., Seung Won Choi, M.D., Jae Min Park, M.D., Gang Hyun Ahn, M.D., \\ Se Kyu Kim, M.D., Joon Chang, M.D., Sung Kyu Kim, M.D., Won Young Lee, M.D., \\ Kyu Ok Choe, M.D.," Dong Hwan Shin, M.D."* \\ Department of Internal Medicine, Diagnostic Radidogy and Pathology \\ Yonsei University College of Medicine, Seoul, Korea
}

The first case of allergic bronchopulmonary aspergillosis(ABPA) was reported by Hinson, et al. in 1952. This was followed by a number of significant description of the disorder. Although typical ABPA initially presents with asthma, fleeting pulmonary infiltrates, and marked eosinophilia, there are many other ways in which the disease may be first manifested. Common radiologic findings in ABPA include pulmonary infiltrates, atelectasis, emphysema, fibrosis, lobar shrinkage with hilar elevation, cavitation, pneumothorax, aspergilloma and central bronchiectasis. We experienced a case of allergic bronchopulmonary aspergillosis presenting rare radiologic finding of bilateral pulmonary masses in chest radiography. With oral corticosteroid treatment, the size of both pulmonary masses was decreased significantly and his asthmatic symptoms were improved. (Tuberculosis and Respiratory Diseases 1999, $46: 260-265$ )

Key words : Allergic bronchopulmonary aspergillosis, Pulmonary mass.

서 론

알레르기성 기관지 폐 아스페르길루스증(Allergic bronchopulmonary aspergillosis : 이하 ABPA)은
1952년 영국에서 Hinson 동이 처음 보고"한 이후 많은 보고가 있었는데 ${ }^{21}$ 기관지천식 및 일시적인 폐침 윤, 호산구증다중을 동반한 전형적인 경우뿐 아니라 매우 다양한 임상 양상을 보이는 비전형적인 경우도 
상당수 보고되고 있다 ${ }^{3-7)}$.

$\mathrm{ABPA}$ 는 기관지천식 혹은 낭종성 폐섬유증 등의 기존 폐질환과 흔하게 동반되어 나타나고 기관지내에 집락을 이루는 Aspergillus fumigatus에 대한 국 소적인 면역반응에 의해서 유발된다 ${ }^{8,9)}$.

$\mathrm{ABPA}$ 는 치료가 적절하게 되지 않으면 비가역적 인 폐손상이 초래될 수 있어서 조기 진단 및 치료가 강조되고 있으나 비전형적인 경우 진단이 늦어질 수 있다. ABPA를 진단하는데는 일반적으로 Rosenberg 등 ${ }^{(0)}$ 의 진단 기준이 이용되지만 스테로이드 사 용 여부 및 질환의 병기에 따라 진단에 어려움이 있어 Aspergillus fumigatus에 대한 혈청학적 특이 $\mathrm{IgE}, \mathrm{IgG}$ 를 측정하여 진단에 이용하기도 한다 ${ }^{8)}$. $\mathrm{ABPA}$ 의 일반적인 방사선학적 소견은 크게 비특이적 인 폐침윤 혹은 특이적인 중심성 기관지확장증의 양상 을 보이는데 ${ }^{11-13)}$, 방사선학적 소견상 드물게 양측성 폐종괴 양상으로 내원한 환자에서 ABPA를 진단하

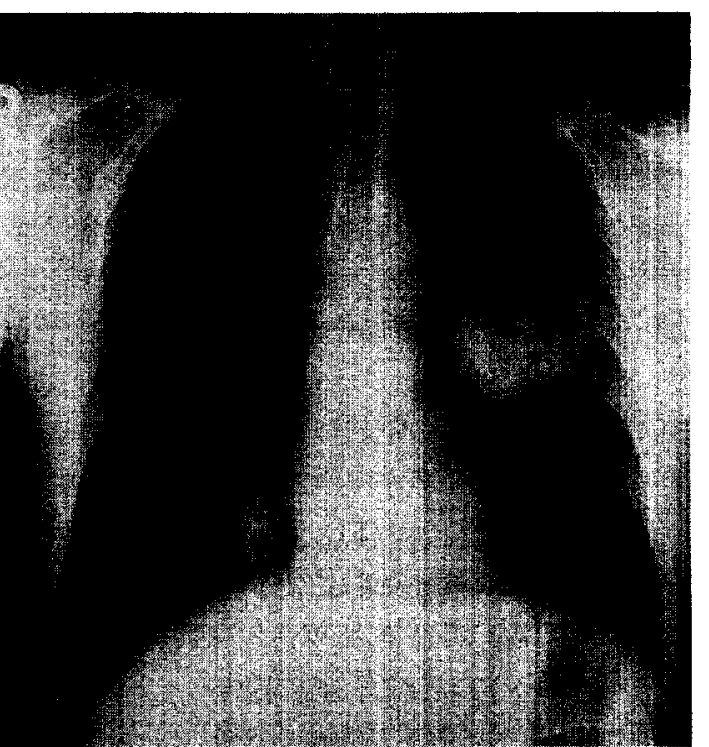

Fig. 1. Chest radiograph shows bilateral masses in right lower and left mid lung fields.
였기에 문헌고찰과 함께 보고하는 바이다.

\section{증 례}

환 자:창ㅎ호남자 33세

주 소: 2 개월간의 화농성 객담, 기침 및 천식 중상 현병력 : 상기 증상으로 개인의원 내원하여 시행한 단 순 ㅎㅎㅇㅂㅜ 엑스선상 양측성 폐종괴 소견을 보여 본원으 로 전원됨.

과거력 : 8 년전 호흡곤란과 천명음으로 타병원에서 입 원치료 받았으며, 가끔 천명음을 동반한 호홉곤란이 있었고 흡연력은 9 갑년이었다.

가족력 : 특이 사항 없었음.

이확적 소견 : 내원 당시 혈압은 $120 / 80 \mathrm{mmHg}$, 맥 박수 분당 84 회, 호흡수 분당 16 회, 체온은 $36.4^{\circ} \mathrm{C}$ 이었다. 급성 병색을 보였으며 흥부 청진상 호흡음은 깨끗하였고 수포음이나 천명음은 청진되지 않았다. 심 음은 규칙적이었으며 심잡음은 들리지 않았고 그 외 다른 검사상 특이소견은 없었다.

검사실 소견 : 혈액검사상 혈색소 $14.8 \mathrm{~g} / \mathrm{dL}$, 안정시 토크릿 $45.3 \%$, 백혈구수 $14780 / \mathrm{mm}^{3}$ (호중구 $83.1 \%$,

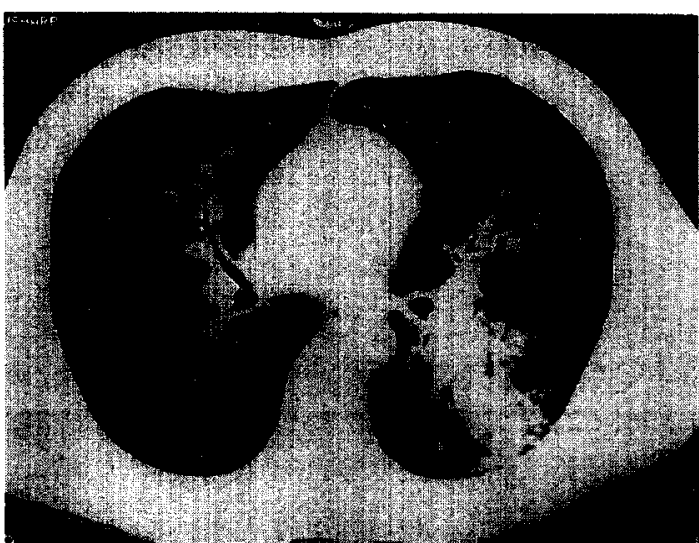

Fig. 2. Chest $\mathrm{Ct}$ scan shows air space consolidation and tubular bronchiectasis with mucoid impaction in lingular divison of left upper lobe and superior segment of left lower lobe. 


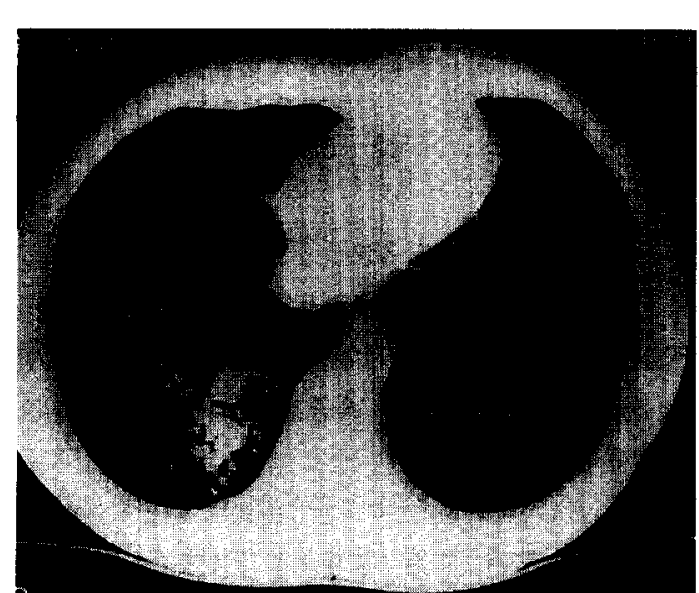

Fig. 3. Chest CT scan shows tubular bronchiectasis with mucoid impaction in posterior basal segment of right lower lobe.

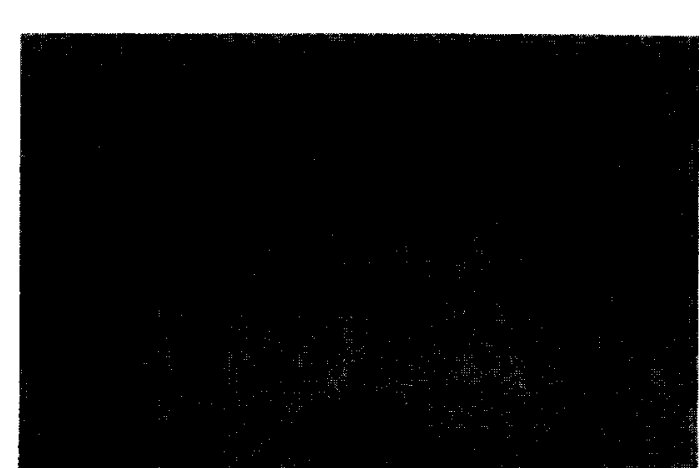

Fig. 4. Transbronchial lung biopsy specimen from superior segment of left lower lobe shows numerous eosinophils and eosinophilic crystal. ( $\mathrm{H} \& \mathrm{E}, \times 400$ )

림프구 $6 \%$, 호산구 $4 \%$ ), 혈소판수 $189,000 / \mathrm{mm}^{3}$, 총호산구수 $590 / \mathrm{mm}^{3}$ 이었으며 일반 화학 검사상 $\mathrm{Ca}$ $9.3 \mathrm{mg} / \mathrm{dL}, \mathrm{P} 2.8 \mathrm{mg} / \mathrm{dL}$, total protein $7.2 \mathrm{~g} / \mathrm{dL}$, albumin $4.1 \mathrm{~g} / \mathrm{dL}$, AST $21 \mathrm{IU} / \mathrm{L}$, ALT $17 \mathrm{IU} / \mathrm{L}$, BUN $17.4 \mathrm{mg} / \mathrm{dL}$, creatinine $1.0 \mathrm{mg} / \mathrm{dL}$ 로 정상소 견이었고 총 $\mathrm{IgE}>3,000 \mathrm{IU} / \mathrm{ml}$ 이었다. 그외 특수검 사상 메타콜린 기관지 유발 검사는 양성 (PC20: $1.44 \mathrm{mg} / \mathrm{dl}$ )이었으며 Aspergillus fumigatus 항원에 대한 혈청 침강 항체반응은 음성이었

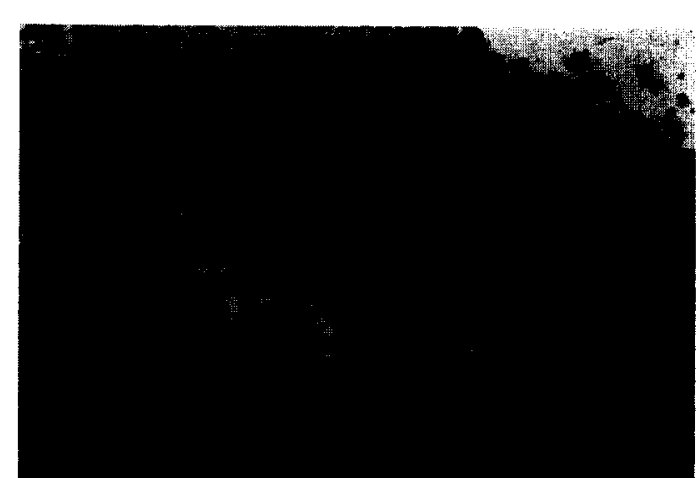

Fig. 5. Transbronchial lung biopsy specimen from superior segment of left lower lobe shows fungi with a few scattered hyphae. (PAS, 400)

다. 피부시험, 특이 $\mathrm{IgE}$ 항체검사, A. fumigatus 항원에 대한 $\mathrm{IgG}$ 항체, 그리고 A. fumigatus 항원 에 의한 기관지유발검사 등은 환자에게 권유하였으나 이후 환자가 증세 호전되면서 거절하여 시행되지 못하 였다.

방사선 소견 : 내원 당시 시행한 단순 흥부 엑스선상 우하폐야에 소엽성 소결절 양상 $(4 \times 2 \mathrm{~cm})$ 과 좌중폐 야에 종괴 양상 $(8 \times 7 \mathrm{~cm})$ 을 보였고(Fig. 1) 훙부 전 산화단충촬영상 좌설상엽과 좌하엽에 점액전을 동반 한 기관지확장중 소견과(Fig. 2) 우하엽에 역시 점액 전을 동반한 관상 기관지확장중 소견을 보였다(Fig. $3)$.

병리 소견 : 경기관지 폐생검상 심한 호산구의 침윤 및 점액전 소견을 관찰할 수 있었고(Fig. 4) 아스페르길 루스 균사가 발견되었다(Fig. 5). 경기관지 폐생검은 기홍, 출혈 등의 합병증의 위험성 때문에 일반적으로 양쪽에서 동시에 하지 않기 때문에 종괴 양상이 뚜렷 한 좌하엽의 상분절에서만 시행하였다.

진단 및 경과 : ABPA 진단하에 1일 경구 prednisolone $40 \mathrm{mg}$ 으로 치료후 증상 호전되고 흥부 엑스선상 종괴의 크기가 감소하는 양상으로 현재 외래에서 추적 관찰중이다. 
- A case of allergic bronchopulmonary aspergillosis shown as bilateral pulmonary masses -

\section{고 찰}

$\mathrm{ABPA}$ 의 원인인 Aspergillus fumigatus는 세계 각지에 분포하고 도처에 서식하며 낭종성 폐섬유중 환 자의 5.8-6.4\% ${ }^{14)}$ 그리고 부신피질 호르몬 의존성 기 관지천식 환자의 $6-10 \%$, 많게는 $28 \%$ 에서 $\mathrm{ABP} \Lambda$ 를 유발한다. 또한 계절성 알레르기 비염 환자의 약 5 $\%$ 에시 혈청 내에 A. fumigatus에 대한 항체가 존 재한다 ${ }^{15)}$. A. fumigatus는 $12^{\circ} \mathrm{C}-53^{\circ} \mathrm{C}$ 에서 번식하 며 그 성장속도가 빠르고 단단한 주형 및 특징적인 집 락형성 그리고 $45^{\circ}$ 각도로 분지하는 특징을 가지며 균사의 크기는 $7-10 \mu \mathrm{m}$ 이다.

$\mathrm{ABPA}$ 의 병태생리는 홉입된 A. fumigatus 둥의 곰팡이가 조직의 직접적인 침범없이 폐쇄성 기관지내 의 점액전(mucoid impaction)에서 집락을 이루어 균사를 존속시키면서 항원 및 mycotoxin을 지속적으 로 방출함으로써 혈청내에 항원에 대한 항체 $(\mathrm{IgA}$, $\mathrm{IgE}, \mathrm{IgG}$ ) 및 과다한 비특이적 $\operatorname{IgE}$ 를 생산하고 이로 인한 면역반웅으로 기관지 점막과 주위 폐조직에 호산 구가 침윤되어 조직손상이 초래된다.

$\mathrm{ABPA}$ 를 진단하는데 일반적으로 이용되는 Rosenberg 둥의 진단 기준 ${ }^{10)}$ 은 (1) 주기적인 기도 폐 쇄(기관지천식) (2) 폐침윤과 함께 말초혈액내 호산 구증다증 (3) A. fumigatus 에 대한 즉시형 피부 과 민성 (4) A. fumigatus에 대한 침강 항체 존재 (5) 혈청 $\mathrm{IgE}$ 가 $1000 \mathrm{ng} / \mathrm{ml}$ 이상 (6) 항부 엑스선상 폐 침윤 소견 (7) 근위 기관지의 확장 둥이다. 그러나 질 환의 병기 및 부신피질 호르몬의 사용어부에 따라 임 상적 및 검사상 특징들이 나타나지 않을 수도 있어 $\mathrm{ABPA}$ 의 조기 진단이나 비전형적인 $\mathrm{ABPA}$ 릅 진단 하는데 어려움이 있다. Greenberger와 Patterson ${ }^{8)}$ 은 A. fumigatus에 대한 혈청 특이 $\operatorname{IgE}(\mathrm{IgE}-\mathrm{Af})$, $\mathrm{IgG}(\mathrm{IgG}-\mathrm{Af})$ 농도의 상숭을 기존 진단 항목에 추가 하여 8 가지 진단 기준을 만들었으며, 이 중 중심성 기 관지확장증소견은 $\mathrm{ABPA}$ 의 진단에 상당히 유용함을 보고하였는데 본 중례에서도 훙부 전산화단충촬영상 중심성 기관지확장증을 확인할 수 있었다. 혈청학적인
항목의 혈청 총 $\mathrm{IgE}$ 는 $\mathrm{ABPA}$ 한자에서 $A$. fumigatus에 대한 비특이적 항체이며 일반적으로 1000 $\mathrm{ng} / \mathrm{ml}$ 이상 높게는 $80,000 \mathrm{ng} / \mathrm{ml}$ 까지 증가되어, 알 레르기 기관지천식 환자에 비해 의미있는 농도의 중가 를 보이며 대부분 $\mathrm{ABPA}$ 의 질병 활성도를 반영하는 줗은 지표로 사용되는데 본 중레에서도 $3,000 \mathrm{ng} / \mathrm{ml}$ 이상으로 중가되어 있었다. A. fumigatus에 대한 침상항체는 $\mathrm{ABPA}$ 환자의 비농축 혈청에서 급성기 나 악화기에 약 $60 \%, 5$ 배 농축 혈청에서는 급성기에 약 $90 \%$ 의 침강항체 양성을 보인닿․ 그러나 $A$. fumigatus 에 대한 침강항체는 비특이적인 검사로 병 원에 입원해 있는 환자의 $9 \%$, 과민성 폐렴 환자의 $27 \%$ 에서 양성, aspergilloma 환자의 거의 모든 경 우에 양성을 보인다 ${ }^{16)}$. 또한 검사에 이용되는 $A$. fumigatus에 대한 칩강 항체의 항원성은 연구 기관 마다 많은 차이가 있어 음성으로 판독되어도 양성을 내제할 수 없기 때군에 항원의 표준화가 절실히 요수 되고 있는 실정인데 본 중례에서는 이와 같은 이유로 침강항체반웅이 음성으로 나은 것으로 생각된다.

$\mathrm{ABPA}$ 에 의해 나타나는 방사선학적 변화는 크게 비특이적인 소견과 특이적인 소견으로 나누는데 ${ }^{11-13)}$, 비특이적 소견은 초기에 점액전, 일시적 폐침윤 둥이 혼하게 나타나며 그 외 무기폐, 기종, 섬유화, 폐문상 승과 동반된 엽상위축둥의 소견을 관찰할 수 있다. 또 한 드물게 공동형성, 기횽, 흥막액, 국균종 둥의 소견 을 보이기도 하는데 국균종은 ABPA 환자외 약 $7 \%$ 에서 발생한다. 이중 폐침윤은 가장 흔하게 나타나는 이상 소건으로 대부분 일과성, 재발싱, 이동성이고 주 로 상엽에서 발생하여 6 개월이상 지속되기도 한다. 이외 다른 소견으로 기종이 나타날 수 있으며 점액전 은 무기뎨를 유발할 수 있고 질환이 진행하면서 후반 기에는 폐섬유화가 발생하여 벌집모양 폐를 형성하기 도 한다. 특이적 소견인 중심성 기관지확장증은 다른 원인으로는 잘 발생되지 않는데 근위 기관지의 확장과 기관지벽의 비후 소견을 보이며 원위 기관지는 점차 얇아지는 양상을 보인다.

본 중례에서는 단순 홍부 엑스선상 우하폐야에 소엽 
성 소결절, 좌중폐야에 종괴의 양상을 보여 악성종양 이나 결핵종 둥의 질병을 의심하였으나 홍부 전산화단 충찰영 및 경기관지폐생검 등을 통해 $\mathrm{ABPA}$ 로 진단 한 경우로 국내에서는 지금까지 전형적인 $\mathrm{ABPA}$ 이 외에 공동을 형성한 증례 ${ }^{3)}$, aspergilloma를 둥반한 ABPA 유사증례 ${ }^{6)}$, 비전형적 천식을 동반한 증례 ${ }^{7)}$ 둥의 본 중례와 같은 비선형적인 방사선학적 소건을 보인 경우가 보고되었다. 폐야의 종괴모양이 감염에 의한 폐침윤일 가능성에 대해서는, 조직검사에서 아스 페르길루스가 소수 발견되었으나 환자의 임상양상과 스테로이드 단독치료에 반응이 있는 점, 그리고 조직 검사 소견 둥으로 미루어 침습성 아스페르길루스증 (invasive or semiinvasive aspergillosis)은 배제하 였다.

$\mathrm{ABPA}$ 를 분류하는 방법은, 입상적으로 5 가지 병 기로 구분 ${ }^{17}$ 하는 방법과, 기관지 확장증이 둥반된 $\mathrm{ABPA}-\mathrm{CB}$ (central bronchiectasis)와 중심성 기관 지확장증 없이 혈청학적으로 양성을 보이는 $\mathrm{ABPA}-$ S(seropositive)의 2 가지로 분류하는 방법 ${ }^{18)}$ 이 있다. 이 중 $\mathrm{ABPA}-\mathrm{S}$ 는 $\mathrm{ABPA}$ 의 조기 형태인지 흑은 질 병 할성도가 상대적으로 낮은 형태인지는 아직까지 확 실하게 밝혀져 있지 않으나 조기에 진단해서 치료하면 비가역적인 폐손상을 방지할 수 있다.

$\mathrm{ABPA}$ 는 일반적으로 기관지천식을 동반하는데 본 중례에서도 환자는 증상 및 메타콜린 기관지 유발 검 사로 천식이 확진되었으며 흥부 전산화단충찰영상 중 심성 기관지확장중이 확인되어 상기한 분류로 판단한 때 $\mathrm{ABPA}-\mathrm{CB}$ 형으로 판단된다.

$\mathrm{ABPA}$ 의 치료를 위해 대부분 경구 스테로이드가 사용되는데, 고용량의 스테로이드 흡입요법이 경구 스 테로이드의 용량을 줄이며 사용기간을 단축시킬수 있 고 일부에서는 고용량 스테로이드 홉입요법만으로도 $\mathrm{ABPA}$ 를 조절하는 것이 가능하다는 보고도 있다 ${ }^{19}$. ABPA 치료에 대한 스테로이드의 기전은 명확하지 않으나 호산구에 의한 기도내 염증을 경감시키고 $A$. fumigatus에 대해 억제되어 있던 중성구나 단핵구의 살상 효과를 회복시키는 것으로 생각된다. 치료에 대
한 반응은 혈청 총 $\mathrm{IgE}$ 를 측정하거나 ELISA 법으로 특이 $\mathrm{IgG}$ 를 측정해서 평가한다. 본 증례에서는 prednisolone으로 치료후 증상이 호전되고 훙부 엑스선상 양측 종괴의 크기가 모두 감소하는 양상을 보여 치료 에 반응이 있는 것으로 생각되었으며 항생제나 항진균 제는 병용하지 않았다. 이외 Itraconazole을 사용하 여 스테로이드의 용량올 줄이고 사용기간을 단축시킬 수 있다는 보고 ${ }^{20)}$ 가 있지만 이는 보조적인 치료이고 또한 그 치료효과를 판정하기에는 더 많은 임상 경험 이 필요할 것으로 생각된다.

결론적으로 기관지천식이나 낭종성 폐섬유증 또는 스테로이드를 사용하고 있는 환자에서 단순 흥부 엑스 선상 종괴의 양상을 보이는 경우에서도 그 빈도가 드 물기는 하지만 $\mathrm{ABPA}$ 를 감별하여야 할 것으로 생각 된다.

\section{참 고 문 헌}

1. Hinson KFW, Moon AJ, Plummer NS : Bronchopulmonary aspergillosis. Thorax $7: 317$, 1952

2. Pepys $\mathrm{J}:$ Hypersensitivity disease of the lungs due to fungi and organic dusts. In: Kallos P, ed. Monographs in Allergy, 1969

3. 유남수, 이경덕, 김준호, 이내숙, 권동원, 조동일, 김재원 : 알레르기성 기관지 폐 아스페르길루스증 1 예. 알레르기 $4: 148,1984$

4. Yoshida N, Suguro H, Kohara F, Akiyama Y, Katoh H, Hashimoto N, Majima T, Yamaguchi $\mathrm{M}$, Horie $\mathrm{T}$, Kawabata $\mathrm{Y}$ : A case of allergic bronchopulmonary aspergillosis with no history of bronchial asthma. Jap J Thorac Dis $30: 2123,1992$

5. Krasnick J, Patterson $R$, Roberts $M$ : Allergic bronchopulmonary aspergillosis presenting with cough variant asthma and identifiable source of Aspergillus fumigatus. Ann 
Allergy Asthma Immunol 75 : 344, 1995

6. 이관식, 신성태, 이현수, 홍천수, 허갑범, 이상용

: Aspergilloma를 동반한 알레르기성 기관지

폐 아스페르길루스증 유사환자 1 예. 알레르기 3

: 179, 1983

7. 박용범, 박중원, 고준상, 황영옹, 훙용국, 신동환, 홍천수 : 비전형적 천식을 동반한 알레르기성 기관 지 폐 아스페르길루스증 1 예. 알레르기 $17: 316$, 1997

8. Greenberger PA, Patterson R: Diagnosis and management of allergic bronchopulmonary aspergillosis. Ann Allergy 56:444, 1986

9. Laufer P, Fink JN, Bruns WT, Unger GF, Kalbfleisch JH, Greenberger PA, Patterson $\mathrm{R}$ : Allergic bronchopulmonary aspergillosis in cystic fibrosis. J Allergy Clin Immunol 73 : 44, 1984

10. Rosenberg M, Patterson R, Mintzer R, Cooper $\mathrm{BJ}$, Roberts $\mathrm{M}$, Harris $\mathrm{KE}$ : Clinical and immunological criteria for the diagnosis of allergic bronchopulmonary aspergillosis. Ann Intern Med $86: 405,1977$

11. Zhaoming W, Lockey RF:A review of allergic bronchopulmonary aspergillosis. J Invest All Clin Immunol $6: 144,1996$

12. Elliott MW, Newman Taylor AJ : Allergic bronchopulmonary aspergillosis. Clin Exper Allergy 27(suppl 1) : 55, 1997

13. Lynch DA : Imaging of asthma and allergic bronchopulmonary mycosis. Radio Clin North Am $36: 129,1998$
14. Simmonds EJ, Littlewood JM, Evans EG : Cystic fibrosis and allergic bronchopulmonary aspergillosis. Arch Dis Child 65 : 507, 1990

15. Grammer LC, Greenberger PA, Patterson $\mathrm{R}$ : Allergic bronchopulmonary aspergillosis in asthmatic patients presenting with allergic rhinitis. Int Arch Allergy Appl Immunol 79 : 246, 1986

16. Fireman P, Slavin RG : Allergic bronchopulmonary aspergillosis. In : Fireman $P$ and Slavin RG, eds. Atlas of Allergies, 2nd ed. p132-3, Mosby-Wolfe Co., Barcelona, Spain, 1996

17. Patterson R, Greenberger PA, Radin RC, Roberts $M$ : Allergic bronchopulmonary aspergillosis: Staging as an aid to management. Ann Intern Med $96: 286,1982$

18. Patterson R, Greenberger PA, Halwig JM, Liotta JL, Roberts $M$ : Allergic bronchopulmonary aspergillosis. Natural history and classification of early disease by serologic and roentgenographic studies. Arch Intern Med $146: 916,1986$

19. Imbeault $B$, Cormier $Y$ : Usefulness of inhaled high-dose corticosteroids in allergic bronchopulmonary aspergillosis. Chest 103 : 1614,1993

20. Denning DW, Van Wye JE, Lewiston NJ, Stevens DA : Adjunctive therapy of allergic bronchopulmonary aspergillosis with itraconazole. Chest $100: 813,1991$ 